\title{
AUDIT SISTEM INFORMASI AKADEMIK PADA AMIK DIAN CIPTA CENDIKIA BANDAR LAMPUNG
}

\author{
Pitrawati $^{1}$, Isnandar Agus ${ }^{2}$ \\ ${ }^{1}$ AMIK Dian Cipta Cendikia, ${ }^{2}$ MTI Institut Informatika dan Bisnis Darmajaya \\ E-mail :pitrawati@dcc.ac.id, isnandaragus@gmail.com
}

\begin{abstract}
Abstrak
AMIK Dian Cipta Cendikia adalah salah satu Perguruan Tinggi yang menerapkan pemanfaatan teknologi informasi kedalam sistem informasi akademik. Rencana strategi Perguruan Tinggi dalam pengembangan sistem informasi belum melalui proses audit sistem informasi sehingga perencanaan sistem informasi tidak sejalan dengan kebutuhan proses bisnis yang diharapkan. Untuk mengatasi hal tersebut maka diperlukan adanya audit sistem informasi akademik untuk melihat maturity level sehingga menghasilkan laporan audit sistem informasi yang dapat digunakan sebagai rekomendasi dalam perencanaan sistem informasi akademik dimasa mendatang. Audit sistem informasi dilakukan dengan menggunakan framework cobit 4.1 pada domain DS11. Teknik pengumpulan data melalui observasi, wawancara dan kuesioner. Kuesioner yang digunakan yaitu kuesioner management awareness dan kuesioner maturity level. Kuesioner management awareness untuk mengukur kinerja detailed control objective berupa manajemen data (DS11.1), pengaturan penyimpanan (DS11.2), media library (DS11.3), penghapusan data (DS11.4), backup dan restore (DS11.5) serta kebutuhan keamanan manajemen data (DS11.6) sedangkan maturity level digunakan untuk mengukur tingkat kematangan sistem informasi untuk kondisi saat ini (as is) maupun kondisi yang diharapkan (to be). Hasil penelitian menyimpulkan bahwa kinerja detailed control objective yang diperoleh dari kuesioner management awareness pada domain DS11 adalah 56,5\% responden menyatakan bahwa proses pengelolaan data masih rendah, 39,6\% responden menyatakan cukup dan 3,9\% responden menyatakan baik. Sedangkan hasil penilaiain maturity level menunjukan bahwa proses DS11 secara keseluruhan berada pada tingkat 2 atau repeatable but intuitive. Sedangkan maturity level yang diharapkan (to be) pada proses DS11 secara keseluruhan berada pada tingkat 4 atau managed and measureable. Rekomendasi perencanaan solusi menuju tingkat kematangan yang diharapkan dilakukan dengan mendefinisikan tindakan perbaikan pada atribut AC, PSP, TA, SE, RA dan GSM.
\end{abstract}

Kata Kunci-- Cobit 4.1, Management Awareness, Maturity Level

\section{PENDAHULUAN}

Sistem informasi akademik adalah salah satu sistem informasi di Perguruan Tinggi yang menyediakan layanan informasi akademik. Tata kelola sistem informasi akademik yang baik mampu menunjang perkembangan Perguruan Tinggi menuju Perguruan Tinggi yang sehat.

Tata kelola sistem informasi yang baik harus mempunyai perancangan sistem informasi yang sesuai dengan visi, misi, tujuan dan strategi pengembangan organisasi (Renstra). Perancangan sistem informasi dilakukan dengan melakukan audit. Audit sistem informasi adalah sebuah kegiatan dalam tata kelola yang mutlak diperlukan dalam rangka mengevaluasi hasil proses bisnis yang terjadi dalam organisasi untuk melihat maturity level.

Audit sistem informasi dapat dilakukan dengan menggunakan framework cobit 4.1. Cobit 4.1 mampu menjadi alat bantu yang dapat memecahkan permasalahan pada It governance dalam memahami dan mengelola resiko serta keuntungan yang berhubungan dengan sumberdaya 
informasi. Hasil audit kemudian digunakan sebagai dasar perencanaan sistem informasi dengan mengacu kepada rencana strategi bisnis organisasi.

Menurut Gondodiyoto (2007) suatu organisasi dapat dianggap sukses membangun teknologi informasi dalam suatu kerangka sistem informasi yang lengkap apabila telah memenuhi kriteria ukuran informasi Kriteria ukuran informasi berdasarkan kerangka kerja COBIT

AMIK Dian Cipta Cendikia adalah salah satu Perguruan Tinggi yang menerapkan pemanfaatan teknologi informasi kedalam sistem informasi akademik. Rencana strategi Perguruan Tinggi yang baru khususnya dalam pengembangan sistem informasi belum melalui proses audit sistem informasi sehingga perencanaan sistem informasi tidak sejalan dengan kebutuhan proses bisnis yang diharapkan.

Berdasarkan uraian latar belakang masalah tersebut, maka rumusan masalah yang akan dibahas dalam penelitian ini adalah bagaimana melakukan audit sistem informasi akademik untuk mengukur tingkat kematangan (maturity level) sistem informasi akademik pada AMIK Dian Cipta Cendikia sehingga dapat memberikan rekomendasi untuk perencanaan sistem informasi akademik dimasa mendatang?

\section{METODE PENELITIAN}

Penelitian ini merupakan penelitian deskriptif. Metode deskriptif merupakan salah satu metode penelitian yang bertujuan untuk mengumpulkan informasi aktual secara rinci yang melukiskan gejala yang ada, mengindentifikasi masalah atau memeriksa kondisi dan praktekpraktek yang berlaku, membuat perbandingan atau evaluasi dan menentukan apa yang dilakukan orang lain dalam menghadapi masalah yang sama dan belajar dari pengalaman mereka untuk menetapkan rencana dan keputusan pada waktu yang akan datang.

Menurut Nazir (2014:44) salah satu jenis penelitian deskriptif adalah survei, metode survei merupakan penyelidikan yang diadakan untuk memperoleh fakta-fakta dari gejala-gejala yang ada dan mencari keterangan-keterangan secara faktual baik tentang institusi sosial, ekonomi, atau politik dari suatu kelompok maupun suatu daerah.

Penelitian deskriptif dilakukan secara kuantitatif agar dapat dilakukan penilaian tingkat kematangan (maturity level). Penelitian ini dilakukan melalui studi kasus dimana lokasi penelitian adalah di AMIK Dian Cipta Cendikia guna mengukur tingkat kematangan sistem informasi akademik dalam rangka mencapai tujuan organisasi didasarkan pada framework COBIT versi 4.1 .

\subsection{Teknik Pengumpulan Data}

Teknik pengumpulan data menggunakan Kuesioner, Observasi dan Wawancara. Kuesioner yang digunakan adalah mangement awareness dan maturity level

Menurut Sangadji dan Sopiah (2010:185) populasi adalah wilayah generalisasi yang terdiri atas:subjek dengan kualitas dan karakteristik tertentu yang ditetapkan oleh peneliti untuk dipelajari dan kemudian ditarik kesimpulannya.

Menurut Arikunto (2006) untuk menentukan sampel apabila subjek kurang dari 100, lebih baik diambil semua sehingga penelitiannya penelitian populasi. Jika subjeknya lebih besar dapat diambil antara $10-15 \%$ atau $20-25 \%$.

Pengambilan sampel penelitian dilakukan berdasarkan keterkaitan penggunaan data akademik pada sistem informasi akademik antara lain Direktur, Pembantu Direktur 1, Pembantu Direktur II, Pembantu Direktur III, Kemahasiswaan, Ketua LPPM, Staf LPPM,, Ka. BAAK, Staf BAAK, Staf PDPT, Prodi MI, Prodi KA, Sekretaris Prodi, Staf Prodi, Ka. Puskom, Staf Puskom, Kepala UPT Sertifikasi, staf UPT Sertifikasi, Ketua PSDM dan staf PSDM. Seluruh sampel yang terbentuk sebanyak 31 responden. 


\subsubsection{Observasi}

Pada penelitian ini dilakukan pengamatan terhadap penggunaan Sistem Informasi Akademik. Peneliti akan mengamati secara langsung proses bisnis dalam pengelolaan data pada Sistem Informasi Akademik di AMIK Dian Cipta Cendikia

\subsubsection{Wawancara}

Wawancara yang dilakukan meliputi identifikasi faktor-faktor kebutuhan informasi pengguna data sistem informasi akademik dengan melakukan tanya jawab langsung dengan narasumber yang terkait guna mendapatkan gambaran umum institusi.

\subsubsection{Kuesioner}

Daftar pertanyaan pada kuesioner disusun dengan mengacu pada framework COBIT 4.1. Data yang diperoleh dari kuesioner tersebut dihitung dengan menggunakan Microsoft Excel dan digunakan untuk mengukur nilai maturity level pada sistem informasi akademik.

Kuesioner management awareness diberikan kepada 31 responden yang terdiri dari unsur pimpinan perguruan tinggi dan tenaga administrasi dengan 14 pertanyaan yang memuat 6 atribut penilaian antara lain DS11.1 : Kebutuhan bisnis untuk manajemen data, DS11.2 : Pengaturan penyimpanan, DS1 1.3 : Media library, DS11.4 : Penghapusan data, DS11.5 : Backup dan restore, DS11.6 : Kebutuhan keamanan manajemen data

Kuesioner maturity level diberikan kepada 31 responden yang terdiri dari unsur pimpinan perguruan tinggi dan tenaga administrasi dengan 6 atribut antar lain Kepedulian dan komunikasi (awareness and communication / AC), Kebijakan, standar dan prosedur (policies, standards and procedures / PSP), Perangkat bantu dan otomatisasi (tools and automation / TA), Keterampilan dan keahlian (skills and expertise / SE), Pertanggungjawaban internal dan eksternal (responsibility and accountability / RA), Penetapan tujuan dan pengukuran (goal setting and measurement / GSM).

\subsection{Kerangka Pikir}

Kerangka berfikir diawali dengan identifikasi masalah dimana tidak sesuainya rencana pengembangan sistem informasi akademik dengan kebutuhan stakeholder dikarenakan belum adanya rekomendasi perbaikan yang dihasilkan dari audit sistem informasi.

Pengumpulan data dilakukan dengan diawali pada penyusunan instrumen penelitian. Pemahaman proses bisnis pada AMIK Dian Cipta Cendikia dilakukan dengan cara mempelajari dokumen-dokumen yang terkait dengan Visi, Misi, Renstra, Standar Operasional Prosedur, kebijakan dan standar mutu sistem informasi akademik di AMIK Dian Cipta Cendikia. Pada tahap ini pula peneliti mendistribusikan kuesioner yang telah disusun kepada seluruh responden dimana kuesioner tersebut disusun dengan mengacu pada framework Cobit 4.1 untuk menilai maturity level dan management awareness pada sistem informasi akademik di AMIK Dian Cipta Cendikia.

Analisis data dilakukan oleh peneliti dengan mengukur maturity level dan Management Awareness dengan menghitung indeks dari kuisioner yang dibagikan ke responden kemudian hasil indeks tersebut dipresentasikan pada tingkat maturity level dan Tingkat Kinerja Detailed Control Objectives (DCO) pada Proses DS-11.

Laporan analisis data diperoleh dari hasil kuesioner yang telah diisi oleh responden akan disusun hasil audit. Audit tersebut berisikan Temuan sekarang (current maturity level) dan harapan pada masa yang akan datang (expected maturity level) dan Analisis Gap untuk melakukan 
analisis interprestasi hasil current maturity level dan expected maturiy level. Pada analisis data ini peneliti melaporkan dalam bentuk analisis identifikasi resiko berupa identifikasi aset, ancaman dan dampak, identifikasi kelemahan kontrol dan identifikasi dampak kegiatan institusi serta melakukan penilaian tingkat kematangan (maturity level).

Rekomendasi diberikan untuk mendefiniskan usulan tindakan perbaikanuntuk mengatasi gap pada setiap atribut dan mendefinisikan indikator dan target tingkat kinerja (KPI dan KGI)

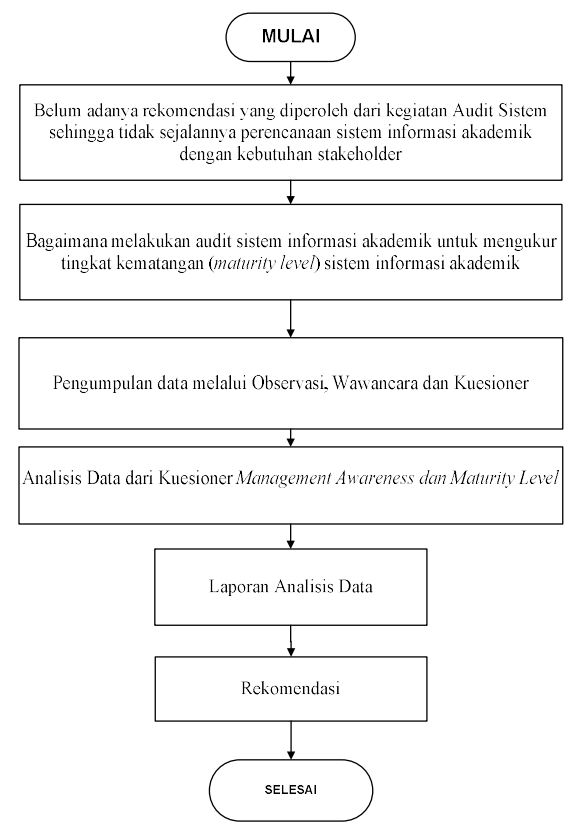

Gambar 1. Kerangka Pikir

\subsection{Analisis Data}

\section{HASIL DAN PEMBAHASAN}

Pengolahan data pada ini bertujuan untuk menentukan posisi maturity level berdasarkan pendekatan COBIT yang telah dicapai instansi pada saat ini. Dalam penelitian ini, digunakan penilaian yang dikemukakan oleh (ITGI,2007) untuk dapatmengukur maturity level dengan langkah-langkah sebagai berikut:

a. Menghitung persentase distribusi jawaban menggunakan perhitungan di bawah ini untuk setiap pertanyaan berdasarkan orientasinya (as is dan to be)

Distribusi Jawaban Kuesioner

$=\frac{\text { Jum } \quad \text { Jawaban }}{J u \quad \text { Pertanyaan }} \times 100 \%$

b. Menghitung indeks kematangan atribut

Indeks Kematangan Atribut

$=\frac{\sum(\text { Jumlah Jawaban } \times \text { Bobot Nilai Kinerja })}{\sum \text { Responden }}$

c. Menghitung indeks kematangan

Indeks Kematangan

$=\frac{\sum \text { Indeks Kematangan }}{\sum \text { Atribut }}$

b. Mengusulkan rekomendasi solusi yang terdiri dari:

1) Pendefinisian usulan tindakan perbaikan untuk mengatasi gap pada setiap atribut. 
2) Pendefinisian indikator dan target tingkat kinerja (KPI dan KGI)

Setelah kuisioner disebarkan maka akan didapat data yang akan diproses untuk dihitung berdasarkan perhitungan maturity level. Untuk selanjutnya dilakukan beberapa tahapan untuk pelaporan yakni:

a. Hasil penilaian berisi temuan sekarang (current maturity level) dan harapan pada masa yang akan datang (expected maturity level).

b. Interprestasi analisa hasil current maturity level dan expected maturity level digunakan analisa gap

Rekomendasi berisi perencanaan strategis sistem informasi untuk mengatasi gap yang ada agar menghasilkan nilai sistem informasi yang optimal. Setelah rekomendasi diserahkan kepada pihak AMIK Dian Cipta Cendikia, maka untuk selanjutnya wewenang perbaikan menjadi tanggung jawab pihak AMIK Dian Cipta Cendikia, apakah akan diterapkan atau hanya menjadi acuan untuk perencanaan startegis sistem informasi dimasa yang akan datang.

\subsection{Hasil Pengolahan Data}

\subsubsection{Hasil Pengolahan Data Management Awareness}

Analisis identifikasi resiko dilakukan dalam proses penilaian kinerja detailed control objective diperoleh dari distribusi kuesioner I management awareness yang dibagikan ke 31 responden. Responden yang dipilih adalah tenaga kependidikan dan pimpinan Perguruan Tinggi. Kuesioner yang dibagikan tersebut kemudian direkapitulasi dengan menggunakan Microsoft Excel. Hasil rekapitulasi tersebut akan digunakan untuk mengidentifikasi resiko dan dampak kepada organisasi.

Tabel 1. Rekapitulasi hasil kuesioner I Management Awareness

\begin{tabular}{|c|c|c|c|c|}
\hline \multirow[t]{2}{*}{ No. } & \multirow[t]{2}{*}{ Bentuk Pertanyaan } & \multicolumn{3}{|c|}{$\begin{array}{c}\text { Distribusi Jawaban } \\
\text { Responden (\%) }\end{array}$} \\
\hline & & $\mathbf{L}$ & $\mathbf{M}$ & $\mathbf{H}$ \\
\hline 1 & Kebutuhan institusi untuk manajemen data & 48,39 & 35,48 & 16,13 \\
\hline 2 & Pengaturan penyimpanan & 54,84 & 41,94 & 3,23 \\
\hline 3 & Media library & 58,06 & 41,94 & 0 \\
\hline 4 & Penghapusan data / Disposal & 61,29 & 35,48 & 3,23 \\
\hline 5 & Backup dan restore & 64,52 & 35,48 & 0 \\
\hline 6 & Kebutuhan keamanan manajemen data & 64,52 & 35,48 & 0 \\
\hline 7 & Pengujian terhadap media backup & 61,29 & 35,48 & 3,23 \\
\hline 8 & Kecepatan proses restorasi & 77,42 & 22,58 & 0 \\
\hline 9 & Keberhasilan proses restorasi & 58,06 & 41,94 & 0 \\
\hline 10 & Keamanan data sensitif setelah disposal & 32,26 & 64,23 & 3,23 \\
\hline 11 & Penangaan insiden kapasitas penyimpanan & 54,84 & 45,16 & 0 \\
\hline 12 & Keandalan sistem karesa proses pemulihan & 51,61 & 45,16 & 3,23 \\
\hline 13 & Kepuasan pengguna atas ketersediaan data & 54,84 & 38,71 & 6,45 \\
\hline 14 & Kepatuhan pada aspek hukum/aturan & 48,39 & 35,48 & 16,13 \\
\hline & Total & 56.5 & 39.6 & 3.9 \\
\hline
\end{tabular}

Berdasarkan tabel 1 maka dapat disimpulkan bahwa 56,5\% responden menyatakan bahwa proses pengelolaan data masih rendah sehingga sangat perlu ditingkatkan, 39,6\% responden menyatakan bahwa proses pengelolaan data sedang dan 3,9\% responden menyatakan bahwa proses pengelolaan data kurang.

Untuk dapat mendiskripsikan secara jelas hasil pengolahan data kuesioner I management awaraness dalam menilai kinerja Detailed Control Objectives pada proses DS-11, maka dilakukan pengelompokan jawaban kuesioner I management awaraness seperti yang telihat pada tabel 2 dibawah ini 
Tabel 2. Pemetaan Hasil Kuesioner I management awaraness

\begin{tabular}{|l|l|c|c|}
\hline No. & \multicolumn{1}{|c|}{ Jawaban } & Nilai Kinerja & Tingkat Kinerja \\
\hline 1 & L (Low) & 1,00 & Kurang \\
\hline 2 & M (Medium) & 2,00 & Sedang \\
\hline 3 & H (High) & 3,00 & Baik \\
\hline
\end{tabular}

Tabel 3. Tingkat Kinerja Detailed Control Objectives (DCO) pada Proses DS11

\begin{tabular}{|c|l|c|c|}
\hline No. & \multicolumn{1}{|c|}{ Detailed Control Objectives (DCO) } & $\begin{array}{c}\text { Nilai } \\
\text { Kinerja }\end{array}$ & $\begin{array}{c}\text { Tingkat } \\
\text { Kinerja }\end{array}$ \\
\hline 1 & DS-11.1: Kebutuhan bisnis untuk manajemen data & 1,68 & Kurang \\
\hline 2 & DS-11.2 : Pengaturan penyimpanan & 1,48 & Kurang \\
\hline 3 & DS-11.3: Media library & 1,42 & Kurang \\
\hline 4 & DS-11.4: Penghapusan data / disposal & 1,42 & Kurang \\
\hline 5 & DS-11.5: Backup dan restore & 1,35 & Kurang \\
\hline 6 & DS-11.6: Kebutuhan keamanan manajemen data & 1,35 & Kurang \\
\hline \multicolumn{2}{|c|}{ Rata-rata } & \multicolumn{3}{|c|}{$\mathbf{1 , 4 5}$} \\
\hline
\end{tabular}

Berdasarkan tabel 3 dapat dilihat rata-rata kinerja pemenuhan Detailed Control Objectives pada DS-11 pengelolaan data sebesar 1,45. Dari nilai rata-rata tersebut maka dapat disimpulkan bahwa tingkat pemenuhan kinerja masih cenderung kurang dan masih harus ditingkatkan dengan rata-rata kinerja. Hal ini dapat dilihat pada grafik tingkat pemenuhan DCO pada proses pengelolaan data (DS-11)

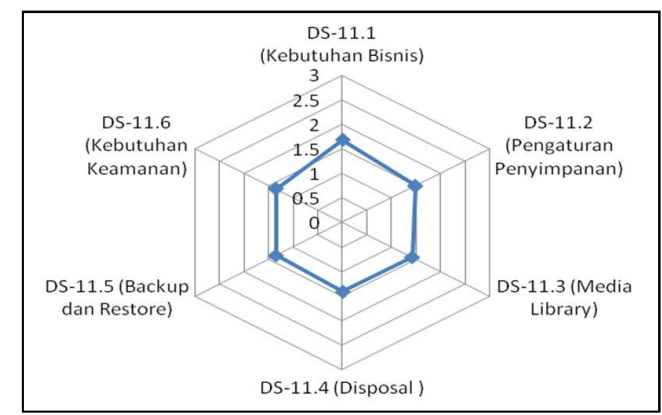

Gambar 2. Grafik tingkat pemenuhan DCO pada DS11

\subsubsection{Hasil Pengolahan Data Maturity Level}

Analisis kuesioner II dilakukan untuk menilai kinerja maturity level dengan mendistribusikan kuesioner II kepada 31 responden. Responden yang dipilih adalah kependidikan dan pimpinan Perguruan Tinggi.

Tabel 4. Rekapitulasi Hasil Kuesioner II Maturity Level

\begin{tabular}{|c|c|c|c|c|c|c|c|c|}
\hline \multirow{2}{*}{ No } & \multirow{2}{*}{ Atribut } & \multirow{2}{*}{ Status } & \multicolumn{6}{|c|}{ Distribusi Jawaban (\%) } \\
\hline & & & $\mathbf{a}$ & b & c & d & $\mathrm{e}$ & $\mathrm{f}$ \\
\hline \multirow{2}{*}{1} & \multirow{2}{*}{$\mathrm{AC}$} & as is & 0.00 & 3.23 & 64.52 & 29.03 & 3.23 & 0.00 \\
\hline & & to be & 0.00 & 0.00 & 3.23 & 32.26 & 64.52 & 0.00 \\
\hline \multirow{2}{*}{2} & \multirow{2}{*}{ PSP } & as is & 3.23 & 41.94 & 45.16 & 9.68 & 0.00 & 0.00 \\
\hline & & to be & 0.00 & 0.00 & 0.00 & 0.00 & 61.29 & 38.71 \\
\hline \multirow{2}{*}{3} & \multirow{2}{*}{ TA } & as is & 3.23 & 48.39 & 48.39 & 0.00 & 0.00 & 0.00 \\
\hline & & to be & 0.00 & 0.00 & 0.00 & 16.13 & 61.29 & 22.58 \\
\hline \multirow{2}{*}{4} & \multirow{2}{*}{ SE } & as is & 0.00 & 32.26 & 67.74 & 0.00 & 0.00 & 0.00 \\
\hline & & to be & 0.00 & 0.00 & 3.23 & 61.29 & 35.48 & 0.00 \\
\hline \multirow[b]{2}{*}{5} & \multirow[b]{2}{*}{ RA } & as is & 0.00 & 0.00 & 35.48 & 61.29 & 3.23 & 0.00 \\
\hline & & to be & 0.00 & 0.00 & 0.00 & 3.23 & 67.74 & 29.03 \\
\hline \multirow{2}{*}{6} & \multirow{2}{*}{ GSM } & as is & 35.48 & 58.06 & 6.45 & 0.00 & 0.00 & 0.00 \\
\hline & & to be & 0.00 & 0.00 & 0.00 & 51.61 & 45.16 & 3.23 \\
\hline \multicolumn{3}{|c|}{ as is } & 6.99 & 30.65 & 44.62 & 16.67 & 1.08 & 0.00 \\
\hline & \multicolumn{2}{|c|}{ to be } & 0.00 & 0.00 & 1.08 & 27.42 & 55.91 & 15.59 \\
\hline
\end{tabular}

Berdasarkan hasil rekapitulasi tersebut dapat diketahui bahwa 44,62\% responden memberikan jawaban "c" atas pernyataan yang berorientasi pada masa saat ini (as is) sedangkan $55.91 \%$ responden menjawab "e" untuk pernyataan yang berorientasi pada masa depan (to be).

Sedangkan pola kecenderungan dapat terlihat jelas pada gambar dibawah ini, dimana posisi tertinggi kurva as is lebih dekat pada jawaban "c" dan posisi tertinggi kurva pada to be terletak pada jawaban "e" 


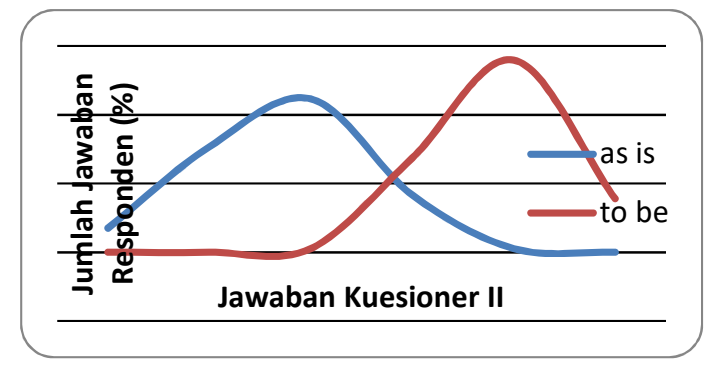

Gambar 3. Kurva Distribusi Jawaban Kuesioner Maturity Level

Untuk mendiskripsikan secara lebih jelas hasil analisis dan kajian tentang maturity level pada masing-masing atribut, maka hasil tersebut dapat mengacu pada model maturity Cobit.

Tabel 5. Pemetaan Hasil Kuesioner II Maturity Level

\begin{tabular}{|c|c|c|l|}
\hline No & Jawaban & Nilai Maturity & \multicolumn{1}{|c|}{ Maturity Level } \\
\hline 1 & A & 0,00 & Non Existent \\
\hline 2 & B & 1,00 & Initial/Ad Hoc \\
\hline 3 & C & 2,00 & Repeatable but Intuitive \\
\hline 4 & D & 3,00 & Defined Process \\
\hline 5 & E & 4,00 & Managed and Measureable \\
\hline 6 & F & 5,00 & Optimized \\
\hline
\end{tabular}

Setiap atribut memiliki nilai kontribusi atau bobot yang sama terhadap maturity level proses DS11, maka untuk kedua status as is maupun to be maturity level dapat dilihat pada tabel 6.

Tabel 6. Nilai dan tingkat maturity proses DS11

\begin{tabular}{|c|c|c|c|c|c|}
\hline \multirow{2}{*}{ No } & \multirow{2}{*}{ Atribut } & \multicolumn{2}{|c|}{ Nilai maturity } & \multicolumn{2}{c|}{ Maturity level } \\
\cline { 3 - 6 } & & As is & To be & As is & To be \\
\hline 1 & AC & 2.32 & 3.61 & 2 & 4 \\
\hline 2 & PSP & 1.61 & 4.39 & 2 & 4 \\
\hline 3 & TA & 1.45 & 4.06 & 1 & 4 \\
\hline 4 & SE & 1.68 & 3.32 & 2 & 3 \\
\hline 5 & RA & 2.68 & 4.26 & 3 & 4 \\
\hline 6 & GSM & 0.71 & 3.52 & 1 & 4 \\
\hline \multicolumn{2}{|c|}{ Rata-rata } & $\mathbf{1 . 7 4}$ & $\mathbf{3 . 8 6}$ & $\mathbf{2}$ & $\mathbf{4}$ \\
\hline
\end{tabular}

Nilai maturity dan maturity level diperoleh bobot dikali dengan jawaban dan seluruh jawaban yang ada dijumlahkan kemudian dirata-ratakan untuk setiap atribut.

Nilai maturity bernilai tidak bulat (bilangan desimal) karena nilai tersebut di presentasikan pada proses pencapaian menuju suatu maturity level tertentu. Sedangkan maturity level lebih menunjukkan tahapan atau kelas yang dicapai dalam proses maturity, yang dinyatakan dalam bilangan bulat.

Berdasarkan tabel 8, maka dapat diketahui bahwa maturity level yang mengacu pada tabel 7 adalah maturity level saat ini (as is) pada proses DS11 keseluruhan berada pada tingkat 2 atau repeatable but intuitive. Sedangkan maturity level yang diharapkan (to be) pada proses DS11, secara keseluruhan berada pada tingkat 4 atau managed and measureable. 


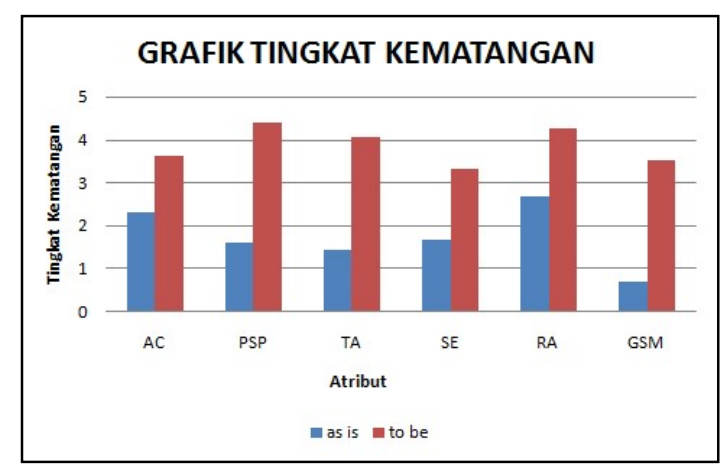

Gambar 4. Grafik Tingkat Kematangan As Is dan To Be dari Atribut Kematangan

Pada gambar 4 diatas dapat tergambar maturity level yang saat ini (as is), diharapkan (to be) dan upaya menutup kesenjangan (gap) yang ada pada sistem informasi akademik

\subsection{Penetapan Strategi Pencapaian Maturity Level}

Penetapan strategi pencapaian maturity (kematangan) diperlukan dengan pertimbangan sebagai berikut:

a. Tahapan kematangan merupakan proses alamiah dalam proses perbaikan, serta merupakan proses pembelajaran dimana setiap tahapan kematangan harus dilalui.

b. Sinergi dapat dilakukan secara optimal bila terjadi keseimbangan tingkat kematangan pada keseluruhan atribut.

c. Perbaikan dilakukan secara bertahap sesuai dengan skala prioritas. Atribut dengan nilai kematangan yang lebih rendah, mendapat prioritas lebih tinggi untuk dilakukan perbaikan.

d. Dengan proses perbaikan secara bertahap sesuai dengan prioritas, maka proses pembelajaran menuju pematangan proses DS11 dalam institusi dapat berlangsung secara efektif.

Dengan mempertimbangkan hal tersebut diatas maka perlu ditetapkan strategi pencapaian perbaikan proses DS11, dengan menciptakan sasaran yang diperlukan dengan cara sebagai berikut:

a. Atribut dengan tingkat kematangan as is 1, mendapat prioritas utama untuk dilakukan langkah perbaikan, mencapai pada tingkat kematangan 2 terlebih dahulu kemudian dilanjutkan kematangan 3. Beberapa atribut yang dimaksud berturut-turut sesuai prioritas adalah GSM dan SE.

b. Atribut dengan tingkat kematangan as is 1, mendapat prioritas kedua untuk dilakukan langkah perbaikan, mencapai pada tingkat kematangan 2 terlebih dahulu kemudian dilanjutkan kematangan 3 dan 4 . Atribut tersebut adalah TA dan PSP

c. Atribut dengan tingkat kematangan as is 2, mendapat prioritas ketiga untuk dilakukan langkah perbaikan, mencapai pada tingkat kematangan 3. Atribut yang dimaksud berturutturut sesuai prioritas adalah $\mathrm{AC}$

d. Atribut dengan tingkat kematangan as is 2, mendapat prioritas keempat untuk dilakukan langkah perbaikan, mencapai pada tingkat kematangan 2 terlebih dahulu kemudian dilanjutkan kematangan 3 dan 4 . Beberapa atribut yang dimaksud berturut-turut sesuai prioritas adalah RA

\subsection{Perencanaan Usulan Tindakan Perbaikan}

Perencanaan usulan tindakan perbaikan diperoleh dari hasil tahapan analisis untuk menjadi pertimbangan utama dalam mendefinisikan perancangan, untuk dapat memberikan suatu usulan tindakan perbaikan berikut ini ada beberapa hal yang penting dalam analisis : 
1. Pada analisis management awareness telah diperoleh data bahwa adanya keperdulian institusi tentang dampak negatif suatu resiko bila proses pengelolaan data (DS11) tidak dikelola dengan baik dan juga diidentifikasi adanya kelemahan kontrol terutama pada pemenuhan detailed control objectives (DCO) pada domain pengelolaan data (DS11)

2. Pada analisis maturity level telah diperoleh tingkat kematangan yang saat ini (as is) maupun yang diharapkan (to be) serta penetapan strategi pencapaian kematangan yang diperlukan, yang dipandang efektif dalam rangka proses pematangan yang diharapkan

\subsection{Perencanaan Usulan Indikator dan Target Tingkat Kinerja}

Perencanaan usulan indikator dan target tingkat kinerja dikelompokan dalam 3 kelompok yaitu :

1. Pencapaian tingkat kematangan 3

Pada kelompok ini proses pematangan atribut bergerak tumbuh dari tingkat kematangan 2 menuju ke tingkat kematangan 3. Pada proses kematangan ini melibatkan atribut SE

2. Pencapaian tingkat kematangan 4

Pada kelompok ini proses pematangan atribut bergerak tumbuh dari tingkat kematangan 1 menuju ke tingkat kematangan 2, tingkat kematangan 2 ke tingkat kematangan 3, tingkat kematangan 3 ke tingkat kematangan 4 . Pada proses kematangan ini melibatkan atribut AC, PSP, TA, RA dan GSM

\subsection{Rekomendasi Solusi}

Rekomendasi solusi indikator dan target tingkat kinerja dilakukan sebagai tindak lanjut dari usulan tindakan perbaikan. Hal ini dilakukan untuk mengukur tingkat capaian dan mengevaluasi kegiatan perbaikan pengelolaan data yang diharapkan dimasa mendatang.

Penilaian atau pengukuran dilakukan baik pada proses pelaksanaanmaupun pencapaian perbaikan. Penilaian tersebut berkaitan dengan proses pengelolaan data adalah penilaian Key Performance Indicator (KPI) dan Key Goal Indicator (KGI), dimana KGI dapat diuraikan lagi dalam Process Key Goal Indicator (PKGI) maupun IT Key Goal Indicator (ITKGI).

Tujuan aktifitas (Activities gols) merupakan keberhasilan bagi tercapainyan tujuan teknologi informasi. Tujuan aktifitas dapat dipandang sebagai critical success factor (CSF) dari proses DS11 yang meliputi kegiatan :

a. Melakukan backup data dan menguji restorasi.

b. Mengelola penyimpanan data onsite dan offsite.

c. Melakukan penghapusan data dan peralatan secara aman.

Key Performance Indicator (KPI) untuk dapat menilai atau mengukur seberapa baik aktifitas diatas telah dilaksanakan, indikator penilaian KPI adalah :

a. Frekuensi terhadap pengujian backup media.

Waktu rata-rata untuk restorasi data.

\section{KESIMPULAN}

Dari hasil penelitian yang telah dilakukan maka, dapat diambil kesimpulan sebagai berikut :

1. Audit sistem informasi akademik yang dilakukan di AMIK Dian Cipta Cendikia, Bandar Lampung dengan menggunakan Framework cobit 4.1 pada domain DS11 (pengelolaan data) untuk menilai tingkat kinerja detailed control objective yangdiperoleh dari kuesioner I managementawarenessdan menilai maturity level melalui kuesioner II, sehingga menghasilkan rekomendasi usulan tindakan perbaikan dan indikator target tingkat kinerja

2. Penilaian tingkat kinerja detailed control objective yangdiperoleh dari kuesioner Imanagement awareness untuk identifikasi asset, ancaman dan dampak, identifikasi kelemahan kontrol, identifikasi dampak kegiatan Institusi, sedangkan penilaian maturity level yang diperoleh dari kuesioner II untuk merepresentasi maturity level danpenetapan strategi pencapaian maturity 
3. Hasil audit untuk mengukur kinerja detailed control objective yang diperoleh dari kuesioner I managementawarenesspada domain DS11 adalah sebagai berikut :

a. $56,5 \%$ responden menyatakan bahwa proses pengelolaan data masih rendah sehingga sangat perlu ditingkatkan dan 39,6\% responden menyatakan bahwa proses pengelolaan data cukup dan 3,9\% responden menyatakan bahwa proses pengelolaan data baik.

b. Kinerja pemenuhan Detailed Control Objectives pada DS-11 pengelolaan data sebesar 1,45 sehingga dapat digambarkan bahwa tingkat pemenuhan kinerja masih cenderung kurang dan masih harus ditingkatkan dengan rata-rata kinerja.

4. Hasil audit maturity level pada sistem informasi akademik dengan menggunakan framework cobit 4.1 adalah sebagai berikut :

a. Hasil rekapitulasi maturity level menunjukan bahwa 44,62\% responden memberikan jawaban "c" atas pernyataan yang berorientasi pada masa saat ini (as is) sedangkan $55.91 \%$ responden menjawab "e" untuk pernyataan yang berorientasi pada masa depan (to be).

b. Hasil penilaian maturity level yang mengacu pada tingkat kematangan yang ada di Cobit 4.1 adalah maturity level saat ini (as is) pada proses DS11 keseluruhan berada pada tingkat 2 atau repeatable but intuitive. Sedangkan maturity level yang diharapkan (to be) pada proses DS11, secara keseluruhan berada pada tingkat 4 atau managed and measureable.

\section{SARAN}

Berdasarkan pembahasan dan kesimpulan maka saran yang dapat diberikan adalah sebagai :

1. Hasil pengukuran dan penilaian kinerja detailed control objective melalui kuesioner I management awareness dan maturity levelmelalui kuesioner II dapat digunakan sebagai salah satu rekomendasi perencanaan usulan tindakan perbaikan dan perencanaan indikator dan target tingkat kinerja sistem informasi akademik.

2. Penilaian maturity level pada sistem informasi akademik pada AMIK Dian Cipta Cendikia, Bandar Lampung hendaknya perlu disempurnakan melalui penelitian berikutnya dengan menambah domain lain yang terdapat di Cobit 4.1

3. Untuk meningkatkan kinerja dari sebuah sistem yang ada di Perguruan Tinggi perlu dibentuknya tim audit yang bersifat tetap sehingga dapat melakukan audit kinerja sistem secara berkelanjutan.

4. Perlu adanya penetapan target maturity level pada Rencana Strategi Perguruan Tinggi (RENSTRA).

\section{UCAPAN TERIMA KASIH}

Penulis mengucapkan terima kasih kepada jurnal redaksi Jupiter yang telah memberikan kesempatan kepada penulis, sehingga artikel ilmiah ini dapat dipublikasikan.

[1] Arikunto, Suharsimi. 2006. Prosedur Penelitian Suatu Pendekatan Praktik. Rineka Cipta, Jakarta.

[2] Gondodiyoto, Sanyoto. 2007.Audit Sistem Informasi Pendekatan Cobit (Edisi Revisi). Mitra Wacana Media, Jakarta.

[3] IT Governance Institute/ITGI. 2007. Framework, Control Objectives, Management Guidelines, Maturity Models, COBIT Version 4.1. IT Governance Institute, Illinois.

[4] Jogiyanto. 2001. Analisa dan Desain Sistem Informasi Pendekatan Terstruktur Teori Dan Praktek Aplikasi Bisnis. Andi, Yogyakarta.

[5] Nazir. 2014. Metodologi Penelitian, Ghalia Indonesia, Bogor

[6] Sangadji dan Sopiah, 2010, Metodologi Penelitian, Andi Offset, Yogyakarta

[7] Sugiono. 2007. Statistik Untuk Penelitian. CV Alfabeta, Bandung.

[8] Surendro, Kridanto. 2009. Implementasi Tata Kelola Teknologi Informasi. Informatika, Bandung.

[9] Indera. 2019. "Sistem Informasi Elektronik Mading (e-mading) UKM Dan Fakultas Ilmu Komputer IIB Darmajaya." OSF Preprints. February 19. doi:10.31219/osf.io/nf4b6. 